\title{
ЕКОЛОГО-ЕКОНОМІЧНІ ДОСЛІДЖЕННЯ ВИКОРИСТАННЯ ПОБІЧНИХ ПРОДУКТІВ ТВАРИННОГО ПОХОДЖЕННЯ
}

\author{
O.I. Фурдичко \\ доктор економі чних наук, професор, академік НААН \\ Інститут агроекології і природокористування $Н A A H$ \\ (Україна, м. Київ; e-mail: agroecologynaan@gmail.com) \\ Л.І. Свалявчук \\ кандидат біологічних наук \\ Інститут агроекологіі і природокористування НАAH \\ (Україна, м. Kиїв; e-mail: svaliavchuklarisa@ukr.net) \\ О.Л. Шевцова \\ Національна академія аграрних наук України \\ (Україна, м. Київ; e-mail: vnka@naas.gov.ua)
}

Проведено ретроспективний аналіз наукової літератури та огляд нормативно-законодавчої бази за темою дослідження. Висвітлено головні переваги ведення птахівництва порівняно з іншими галузяли тваринництва. Показано екологічні наслідки для навколищнъого природного середовища внаслідок динамічного розвитку виробництва птахопродукизї. Відповідно до Закону України «Про побічні продукти тваринного походження, не призначених для споживання людиною», відходи тваринництва класиббіковано за трвома категоріями. Продукти, шјо належать до категорї I, є найнебезпечнішили, ї необхідно видаляти, а ввезення продуктів иієї категорї на територію України суворо заборонено. Продукти категорї II та III піддаються переробиі для виробництва органо-мінералъних добрив та кормів тваринного походження. Усі суб'єкти господарювання, діяльність яких призводить до утворення відходів тваринного походження, мають дотрилуватисъ вимог Закону України «Про відходи» та забезпечувати ї подальиу утилізаиію. У разі недотримання підприємством усіх законодавчих норм щодо поводження з відходами, передбачається штраяб відповідно до встановленого законодавства. Висвітлено, шо Київсъка обл. належить до лідерів із виробництва продукиї тваринництва $і$ створює значне антропогенне навантаження, що становить $170 \%$ від середнъого показника в Україні.

Ключові слова: еколого-економічні дослідження, твариннищтво, птахівнищтво, побічні проӘукти тваринного походження.

Постановка проблеми. На сьогодні вітчизняне виробництво продукції птахівництва $€$ одним із найбільш економічно привабливих та конкурентоспроможних видів агробізнесу, про що свідчить щорічна стійка динаміка зростання виробництва м'яса птиці і яєць. Забезпечення потреби населення у повноцінному харчовому білку на 40-65\% відбувається завдяки продукції птахівництва. Але, через високу конкуренцію на споживчих ринках виробництво має постійно удосконалювати технологію для вирощування птиці, переробки птахопродукції, впровадження сучасних стандартів якості, стратегію планування тощо. Окрім того, птахівництво має високий експортний потенціал та переспективи його нарощування, що належить до одного із стратегічних напрямів підвищення ефективності агропромислового комплексу до 2020 p.
Аналіз літературних джерел дає підстави стверджувати, що валове виробництво м'яса всіх видів тварин має вирости до 465 млн т у 2050 р. На сьогодні виробництво м'яса птиці займає II місце після виробництва свинини, але стратегічні тенденції виробництва м'яса в світі свідчать, що у 2020 р. м'ясо птиці буде займати I місце. Нині країнами-лідерами з виробництва м'яса птиці є США, Китай, Бразилія і Росія $[1 ; 2]$.

Перевагами ведення птахівництва порівняно з іншими галузями тваринництва, є: біологічні особливості птиці, висока продуктивність, швидка енергія росту і розвитку, короткий ембріональний період, рентабельність оплати корму приростом живої маси, великий забійний вихід, смакові і технологічні якості птахопродукції. До організаційно-економічних переваг птаховиробництва належать здатність 
швидкого відтворення поголів'я і обігу стада; відсутність сезонності виробництва і можливість рівномірної цілорічної реалізації продукції безпосередньо як на ринку, так і в переробленому вигляді. Оскільки м'ясо і яйця — це продукти першої необхідності, попит на них є постійним, масштаби виробництва - гнучкими, і мало що залежать від площі земельних угідь господарств, але, наголосимо, розвиток комбікормової промисловості і зернового ринку мають визначальний вплив на розвиток птахопідприємств.

Економічна віддача корму за вирощування птиці в 3-4 рази є вищою, ніж за вирощування свиней, великої та дрібної рогатої худоби, тому і собівартість м'яса птиці є найнижчою, тобто це і є найбільш сприятливим чинником для підвищення попиту на продукти птахівництва, що доступні навіть для споживачів 3 невисокими доходами.

Однак стрімкий динамічний розвиток, інтенсифікація виробництва птахопродукції та збільшення розмірів птахопідприємств призводить до негативних екологічних наслідків [3; 4]. Унаслідок трансорормацїї птахівництва на промислову основу та створення потужних птахокомплексів із багаточисельним поголів' ям птиці (до сотні тисяч на одній птахофермі) виникла проблема використання та утилізації значних обсягів побічної продукції галузі (пташиного посліду з підстилкою, відходів інкубації, забою та падежу птиці тощо). Це є біологічною загрозою не тільки для птахогосподарства, але й може слугувати джерелом емісії масштабного забруднення атмосорери, грунту та води токсичними речовинами, збудниками інфекційних та інвазійних хвороб [5].

Аналіз останніх досліджень та публікацій. Основною проблемою, що буде стосуватись тваринництва у майбутньому, є екологічний стан навколишнього природного середовища. За останні 10 років інтенсивного розвитку промислового птахівництва увага вітчизняних дослідників I.I. Панікаря, О.М. Царенко, В.П. Бородая, В.В. Германа, Л.I. Моклячук, В.О. Пінчука, О.В. Тертичної, О.А. Марченко, М.П. Кейван, О.П. Бригас була спрямована на розв'язання проблем як-от: оцінка забруднення атмосферного повітря викидами шкідливих газів та пилу, ї впливу на лісові екосистеми і трансорормацію фрітоценозу; забруднення грунту та його вплив на мікробоценоз; зменшення видового біорізноманіття ентомофрауни; екологічна оцінка стічних, зворотних та поверхневих вод в умовах виробництва продукції птахівництва [6-8].

Виділення невирішених раніше частин загальної проблеми. Найчастіше забруднення довкілля птахопідприємствами відбувається через недосконалість застосування технологій виробництва та технічних засобів, недотримання встановлених екологічних вимог. Тому проблема знешкодження, використання та утилізації побічної продукції птахівництва є надзвичайно актуальною. Провідні науковці використовують у своїх працях важливі практичні розрахунки і математичні методи аналізу для прогнозування розвитку галузі на перспективу. Однак деякі важливі аспекти ефективного розвитку птахівництва ще й досі перебувають на стадії розробки та удосконалення [9]. Дотримання нормативно-правової бази та класифікація побічної продукції тваринництва відповідно до законодавства України є одним із важливих критеріїв оцінювання негативного впливу птахопідприємств на навколишнє природне середовище.

Метою дослідження $є$ аналіз тенденцій розвитку птахівництва в Україні за останні роки, екологічна характеристика та вплив на навколишнє природне середовище використання побічної продукції тваринного походження за виробництва продукції птахівництва.

Матеріали та методи. За темою дослідження здійснили ретроспективний аналіз вітчизняної літератури та нормативно-правових документів. За допомогою аналітичних методів і методів узагальнення опрацювали статистичні матеріали про поголів' я сільськогосподарських тварин і виробництво продукції птахівництва Державної служби статистики України [10].

Викладення основного матеріалу дослідження. За інформацією органів статистики, станом на 01.11.2018 р. порівняно з відповідною датою 2017 р. у сільськогосподарських підприємствах поголів' я великої рогатої худоби (ВРХ) скоротилося на $3,2 \%$, або на 38,5 тис. голів (до 1150,3 тис. голів), дрібної рогатої худоби (ДРХ)на $2,1 \%$, або на 4,1 тис. голів (до 191,3 тис. голів). Поголів' я свиней зросло на 1,2\%, або на 42,1 тис. голів (до 3434,8 тис. голів); птахопоголів' я птиці зросло на 9,1\%, або на 10306,1 тис. голів (до 122948,6 тис. голів) (рис. 1).

У сільськогосподарських підприємствах 24-х адміністративних областей України чисельність поголів'я птиці налічує 122 948,6 тис. голів. Лідирують у цьому напрямі області: Вінницька — 25 012,3 тис. гол; Черкаська 20 633,2; Київська - 20 459,1; Дніпропетровська - 15 255,3 тис. гол.

3 огляду на вищенаведені статистичні дані можна зробити висновок, що виробництво птахопродукції з кожним роком зростає, відповідно нагромаджуються і обсяги побічної продукції птахівництва, що за неналежного використання та утилізації спричиняє шкоду навколишньому природному середовищу. 
Рис. 1. Поголів'я сільсъкогосподарсъких підприєлств в Україні станом на 1 листоnaวa 2018 p.

Джерело: дані Державної служби статистики України.

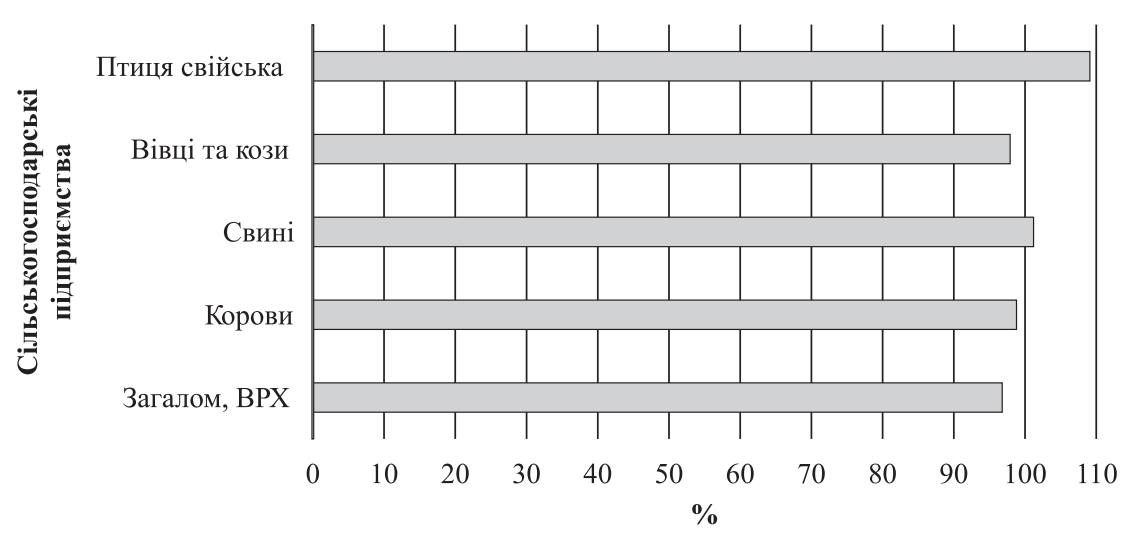

Основними нормативними документами у цій галузі є:

1. Закон України «Про відходи» від 5 березня 1998 р. № 187/98-ВР.

2. Закон України «Про побічні продукти тваринного походження, не призначених для споживання людиною» від 7 квітня 2015 р. № 287-VIII.

3. Закон України «Про державний контроль за дотриманням законодавства про харчові продукти, корми, побічні продукти тваринного походження, здоров'я та благополуччя тварин» від 18 травня 2017 р. № 2042-VIII (набрав чинності 04.04.2018 р.).

Відповідно до нормативно-правової бази України з 9 травня 2016 року набув чинності Закон України (ЗУ) «Про побічні продукти тваринного походження, не призначених для споживання людиною». Документ визначає організаційні та правові засади діяльності фізичних та юридичних осіб, що обумовлено утворенням, збиранням, перевезенням, зберіганням, оброб- кою та переробкою, утилізацією, видаленням побічних продуктів тваринного походження, не придатних для споживання людиною; гармонізує законодавство України у сорері утилізації відходів тваринного походження з вимогами ЄС. Стратегія утилізації відходів та побічної продукції передбачає технічну модернізацію підприємств, підбір оптимальних рішень щодо подальшого перероблення й використання посліду, підстилкових матеріалів і стічної води екобезпечними та економічно вигідними методами [11].

Відповідно до прийнятого ЗУ, побічними продуктами тваринного походження, не призначеними для споживання людиною, є: туша або частини туш забитих, загиблих тварин, сировина та продукти тваринного походження, не призначені або непридатні для споживання людиною. Залежно від рівня ризику для здоров'я людини та тварин, побічні продукти тваринного походження поділяють на три категорії (табл. 1).

Таблицяя 1

Побічні продукти тваринного походження

\begin{tabular}{|c|c|}
\hline № & Категорія \\
\hline \multicolumn{2}{|r|}{ Категорія I } \\
\hline 1 & $\begin{array}{l}\text { Туші та їх частини, у т. ч. шкіра (тварин, підозрюваних у зараженні губчастоподібною ен- } \\
\text { цефалопатією; забитих (загиблих) унаслідок вжиття заходів із ліквідації губчастоподібної } \\
\text { енцефралопатії; тварин, що використовуються для наукових цілей; диких тварин, що під- } \\
\text { озрюються у зараженні хворобами, які передаються людям або тваринам; тварин із зоопарку } \\
\text { та цирку) }\end{array}$ \\
\hline 2 & $\begin{array}{l}\text { Ризиковий матеріал та уся туша або частини туш загиблих тварин, в яких не видалено ри- } \\
\text { зиковий матеріал на момент утилізації чи видалення; }\end{array}$ \\
\hline 3 & $\begin{array}{l}\text { Побічні продукти тваринного походження, зібрані під час очищення стічних вод згідно з } \\
\text { правилами вжиття ветеринарно-санітарних заходів з потужностей (об'єктів) з оброблення, } \\
\text { переробки побічних продуктів тваринного походження, що належать до категорії I, або під- } \\
\text { приємств, де видаляється ризиковий матеріал }\end{array}$ \\
\hline 4 & $\begin{array}{l}\text { Небезпечні побічні продукти тваринного походження, що не підлягають утилізації (побічні } \\
\text { продукти тваринного походження, заражені чи забруднені збудниками сибірки, емфізематоз- } \\
\text { ного карбункула, чуми ВРХ, ящура, чуми верблюдів, сказу, туляремії, правця, злоякісного } \\
\text { набряку, катаральної лихоманки ВРХ і овець, африканської чуми свиней, ботулізму, сапу, } \\
\text { міксоматозу, геморрагічної хвороби кролів, грипу птахів, хвороби Ньюкасла) }\end{array}$ \\
\hline
\end{tabular}


Закінчення табличі 1

\begin{tabular}{|c|c|}
\hline № & Категорія \\
\hline 5 & $\begin{array}{l}\text { Суміші побічних продуктів тваринного походження, що належать до категорії I, з побічними } \\
\text { продуктами тваринного походження, що належать до категорії II та/або III. }\end{array}$ \\
\hline \multicolumn{2}{|r|}{ Категорія II } \\
\hline 1 & $\begin{array}{l}\text { Туші та їх частини, крім продуктів категорії III, тварин, що загинули від інфекційних хвороб, } \\
\text { у т. ч. тварин, підозрюваних у зараженні та/або захворюванні, а також репродуктивний ма- } \\
\text { теріал, не призначений для селекційних цілей, плоди, ембріони, відходи інкубації, отримані } \\
\text { від таких тварин }\end{array}$ \\
\hline 2 & $\begin{array}{l}\text { Побічні продукти тваринного походження, що містять забруднювальні речовини, які пере- } \\
\text { вищують допустимий рівень, встановлений згідно із законодавством }\end{array}$ \\
\hline 3 & $\begin{array}{l}\text { Продукти тваринного походження, визначені непридатними для споживання людиною } 3 \\
\text { огляду на зараження інфекційними хворобами }\end{array}$ \\
\hline 4 & $\begin{array}{l}\text { Залишки, зібрані під час очищення стічних вод згідно з правилами вжиття ветеринарно- } \\
\text { санітарних заходів з потужностей (об’єктів) з оброблення, переробки побічних продуктів } \\
\text { тваринного походження, що належать до категорії II, або з боєнь, крім тих, що є побічними } \\
\text { продуктами тваринного походження, що належать до категорії I, або контактували з такими } \\
\text { побічними продуктами тваринного походження }\end{array}$ \\
\hline 5 & $\begin{array}{l}\text { Продукти тваринного походження, імпортовані/експортовані і не відповідають вимогам за- } \\
\text { конодавства щодо якості та безпечності харчових продуктів }\end{array}$ \\
\hline 6 & Гній \\
\hline 7 & $\begin{array}{l}\text { Суміші побічних продуктів тваринного походження, що належать до категорії II, з побічними } \\
\text { продуктами тваринного походження, що належать до категорії III. }\end{array}$ \\
\hline \multicolumn{2}{|r|}{ Категорія III } \\
\hline 1 & $\begin{array}{l}\text { Туші та їх частини або органи сільськогосподарських тварин і птиці, диких тварин, які вна- } \\
\text { слідок передзабійного огляду визнані придатними для споживання людиною, але після забою } \\
\text { з будь-яких причин не використані для такого споживання, крім жуйних тварин, що потре- } \\
\text { бують дослідження на губчастоподібну енцефалопатію }\end{array}$ \\
\hline 2 & $\begin{array}{l}\text { Туші жуйних тварин та їх частини, що досліджені на губчастоподібну енцефалопатію } \\
\text { і отримали негативну оцінку, у т. ч. шкіра та її обрізки, роги і копита, включаючи фраланги і } \\
\text { зап’ясток, п’ясток, передплесну і плесну кістки }\end{array}$ \\
\hline 3 & $\begin{array}{l}\text { Побічні продукти тваринного походження, що утворюються під час виробництва продукції, } \\
\text { призначеної для споживання людиною, у т. ч. жирова тканина забитих на бійні тварин, } \\
\text { яких не виявлено ознак захворювання, знежирені кістки, шкварки, шлам з центрифуги або } \\
\text { сепаратора від переробки молока }\end{array}$ \\
\hline 4 & $\begin{array}{l}\text { Побічні продукти тваринного походження з інкубатора, яйця, яйцепродукти, у т. ч. пір'я, } \\
\text { голови, лапи, яєчна шкаралупа, забиті курчата, що походять від птиці, в якої не виявлено } \\
\text { ознак інфекційних захворювань, що можуть передаватися людині або тварині }\end{array}$ \\
\hline 5 & $\begin{array}{l}\text { Кров тварин, які не виявляли ознак захворювання, що передається через кров людині чи } \\
\text { тварині, і були забиті на бійні після того, як їх визнано придатними на забій для споживання } \\
\text { людиною }\end{array}$ \\
\hline 6 & $\begin{array}{l}\text { Кров, плацента, шерсть, пір'я, щетина, роги, копита, отримані від живих тварин, які не ви- } \\
\text { являли ознак захворювання, що передається людині або тварині, крім крові жуйних тварин, } \\
\text { що потребують дослідження на губчастоподібну енцефралопатію }\end{array}$ \\
\hline 7 & $\begin{array}{l}\text { Водні організми (гідробіонти) та їх частини, крім морських ссавців, у яких не виявлено ознак } \\
\text { інфекційними захворювань, що можуть передаватися людині або тварині, виловлені з метою } \\
\text { реалізації на ринку }\end{array}$ \\
\hline 8 & $\begin{array}{l}\text { Побічні продукти тваринного походження з водних організмів (гідробіонтів), виловлених } 3 \\
\text { метою реалізації на ринку, які утворюються під час виробництва продукції для споживання } \\
\text { людиною }\end{array}$ \\
\hline 9 & $\begin{array}{l}\text { Туші та/або частини туш гризунів, зайцеподібних хутрових звірів, крім побічних продуктів } \\
\text { тваринного походження, що належать до категорій I і II }\end{array}$ \\
\hline 10 & $\begin{array}{l}\text { Корми тваринного походження, що не використовуються для годівлі тварин, у т. ч. через } \\
\text { проблеми виробництва або дефекти упаковки чи інші дефекти, що не становлять ризику для } \\
\text { людини або тварин }\end{array}$ \\
\hline 11 & $\begin{array}{l}\text { Харчові продукти тваринного походження, що є непридатними для споживання людиною, } \\
\text { але безпечними для згодовування тваринам. }\end{array}$ \\
\hline
\end{tabular}


Відповідно до ЗУ «Про побічні продукти тваринного походження, не призначених для споживання людиною» продукти, які належать до категорії I піддаються видаленню, а ввезення продуктів цієї категорії на територію України заборонено.

Щодо побічних продуктів категорії II відповідно до вказаного нормативу їх слід: переробляти на органічні добрива після стерилізації та знезараження; компостувати або перетворювати на біогаз; після стерилізації можна використовувати для фрармацевтичного, сільськогосподарського або промислового виробництва, крім кормовиробництва.

Побічну продукцію категорії III після обробки у спосіб стерилізації під тиском або іншими методами слід використовувати для виробництва кормів тваринного походження, крім тих побічних продуктів, що змінились внаслідок псування чи розкладання і становлять ризик для здоров'я людини або тварин; переробляти на органічні добрива, компостувати чи перетворювати на біогаз; перетворювати відповідно до технологій, обумовлених виробництвом продукції.

На ринок може потрапляти продукція II та III категорії, лише на об'єкти, зареєстровані у встановленому порядку. Такі продукти необхідно маркувати оператором ринку та мати чітко викладену інформацію відповідно до загальноприйнятих норм.

Органо-мінеральні добрива, утворені внаслідок переробки побічної продукції тваринного походження, можливо розміщувати на ринку, за умови, якщо вони належать до категорії II та III; вироблені у відповідних установах та утворені внаслідок перетворення побічної тваринної продукції на біогаз чи компост.

Згідно із статистичними даними, останніми роками з понад 13,5 млн т утворених сільськогосподарських відходів наймасовішими є:

- відходи рослинного походження (7742 тис. т, або 57\%);

- тваринні екскременти, сечовина і гній (4938 тис. т, або 37\%);

- відходи тваринного походження та змішані харчові відходи (897 тис. т, або $6 \%)$.

Особливо слід наголосити, що на території України дозволено утилізувати тільки побічну продукцію тваринництва, утворену на території нашої держави. Якщо немає інформації щодо територіального походження відходів, то їх утилізацію можливо здійснювати тільки за рішенням надзвичайної протиепізоотичної комісії.

Щодо основних порушень сільськогосподарських підприємств з утилізації побічних продуктів тваринного походження, слід виокремити такі: відсутність даних обліку та контролю за операціями з відходами; відсутність або фальсифікація даних у звітності підприємств щодо утворення, використання та утилізації побічних продуктів тваринництва; самостійне спалювання та захоронення відходів.

У разі недотримання сільськогосподарськими підприємствами відповідних законодавчих норм щодо утилізації відходів, (а саме статей 82-82-5 Кодексу України про адміністративні правопорушення), то передбачається штраф у розмірі 340-1360 грн. для фрізичних та 850-1700 грн. для юридичних осіб. Усі суб'єкти господарювання, діяльність яких призводить до утворення відходів тваринного походження, мають дотримуватись вимог ЗУ «Про відходи», зокрема статті 35-2, та забезпечувати подальшу утилізацію цих відходів.

Як відомо, Київська обл. належить до лідерів із виробництва продукції тваринництва. Науковцями Інституту агроекології і природокористування НААН: О.В. Тертичною, В.О. Пінчуком, В.П. Бородаєм у 2015 р. було розраховано обсяги твердих відходів у тваринництві. За підрахунками тверді відходи ВРХ становлять 252,6 тис. т/рік; свинарства - 533, 8 тис. т/рік; птахівництва - 1026,5 тис. т/рік. Загалом, обсяги твердих відходів від тваринництва у Київській обл. становлять 1812,9 тис. т/рік, без урахування накопичених відходів. Антропогенне навантаження на територію Київської обл. від твердих відходів тваринництва, загалом становить 64,7 т/км² земельної площі/рік, або $170 \%$ від середнього показника в Україні [12].

Висновки. Еколого-економічні дослідження є важливими та перспективними для вирішення питань щодо використання побічних продуктів тваринного походження у сільськогосподарських підприємствах. Вони передбачають дотримання відповідної нормативно-законодавчої бази, освоєння технологій зберігання, використання та видалення відходів, впровадження яких за відповідності до сільськогосподарського виробництва міжнародним природоохоронним вимогам забезпечить отримання додаткової конкурентоспроможної переваги на ринку продукції та, наприклад, у зниженні витрат на мінеральні добрива. Необхідно проводити екологізацію виробництва для зниження негативного впливу на навколишнє природне середовище, покращення еколого-економічних показників сільськогосподарських підприємств, а також удосконалювати систему екологічного моніторингу, здійснювати перехід на безвідходні технології та забезпечувати виробництво екологічно безпечної продукції. 


\section{СПИСОК ВИКОРИСТАНИХ ДЖЕРЕЛ}

1. Лисицын А.Б. Мировая практика формирования качества мясного сырья и требования к нему перерабатывающей промышленности // Мясная индустрия. 2016. № 9. С. 6-9.

2. FAO Statistical Pocketbook 2015 / FAO. Rome.: Food and Agriculture Organization of the United Nations, 2015. 232p. [Електронний ресурс]. Режим доступу: http://www.fao.org/3/a-i4691e.pdf

3. Rodić $V$. The influence of instruments for environmental protection to livestock production // Contemporary agriculture. 2006. № 55 (1-2). P. 42-47.

4. Wossink A., Wefering F. Hot Spots in Animal Agriculture. Emerging Federal Environmental Policies and the Potential for Efficiency and Innovation Offsets, Int. J. Agricultural Resources, Governance and Ecology. 2003. № 2. P. 228-242.

5. Герман В.В. Екологічна безпека при виробництві тваринницької продукції // Агроекологічний журнал. 2009. № 2. С. 5-8.

6. Масберг I.В., Кейван М.П., Тертична О.В., Бригас О.П. Біоіндикація стану атмосферного повітря в зоні діяльності тваринницьких комплексів // Агроекологічний журнал. 2014. № 1. С. 40-42.

7. Моклячук Л.И., Лукин С.М., Козлова Н.П., Марткоплишвили М.М. Загрязнение окружающей среды химически активным азотом из сельскохозяйственных источников: проблема и пути решения // Агроекологічний журнал. 2014. № 1. С. 13-21.

8. Тертична O.В., Бородай В.П. Екологічні засади розвитку промислового птахівництва // Агроекологічний журнал. 2015. № 2, С. 6-12.

9. Бойко Л.О., Бойко В.О., Аверчева Н.О. Розробка прогнозу та перспективи розвитку галузі птахівництва до 2020 року // Технологический аудит и резервы производства. 2016. № 4/6 (30), С. 34-40.

10. Державна служба статистики України [Електронний ресурс]. Режим доступу: http://www.ukrstat. gov.ua

11. Закон України «Про побічні продукти тваринного походження, не призначені для споживання людиною. Відомості Верховної Ради України. 2015. № 24. С. 171.

12. Тертична О.В., Пінчук О.В., Бородай В.П., Степанов Р.А. Тенденції розвитку та екологічні проблеми промислового тваринництва сучасної агломерації // Вісник аграрної науки. 2016. № 6. С. 54-59.

\section{Інформація про авторів}

Фурдичко Орест Іванович - доктор економічних наук, доктор сільськогосподарських наук, професор, академік НАAН, директор, Інститут агроекології та природокористування НАAН, (Україна, 03143, м. Київ, вул. Метрологічна, 12; e-mail: agroecologynaan@gmail.com)

Свалявчук Лариса Іванівна — кандидат біологічних наук, науковий співробітник, Інститут агроекології і природокористування НАAН (Україна, 03143, м. Київ, вул. Метрологічна, 12; е-mail: svaliavchuklarisa@ukr.net)

Шевцова Ольга Леонідівна - начальник відділу наукових кадрів та аспірантури Національної академії аграрних наук України (Україна, 01010, м. Київ, вул. Михайла Омельяновича-Павленка, 9; e-mail: vnka@naas.gov.ua)

O.I. Furdychko

Doctor of Economics, Professor Academician of NAAS

Institute of Agroecology and Nature Management of NAAS (Ukraine, Kyiv; e-mail: agroecologynaan@gmail.com)

L.I. Svalyavchuk

Candidate of Biological Sciences

Institute of Agroecology and Nature Management of NAAS

(Ukraine, Kyiv; e-mail: svaliavchuklarisa@ukr.net)

O.L. Shevtsova

National Academy of Agrarian Sciences of Ukraine (Ukraine, Kyiv; e-mail: vnka@naas.gov.ua)

\section{ECOLOGICAL AND ECONOMIC RESEARCHES IN THE USE OF BY-PRODUCTS OF ANIMAL ORIGIN}

It was conducted a retrospective analysis of scientific literature and a review of the regulatory and legislative framework on the subject of research. It was shown the main advantages of poultry farming are compared with other branches of animal husbandry. Ecological effects for the environment are shown due to the dynamic development of poultry production. In accordance with the Law of Ukraine "On 
by-products of animal origin not intended for human consumption" livestock wastes are classified into three categories. Products in category I are the most dangerous, they should be removed, and import of products of this category to the territory of Ukraine is strictly prohibited. Products of categories II and III are subject to processing for the production of organo-mineral fertilizers and feed of animal origin. All economic entities, the activity of which leads to the formation of animal waste, must comply with the requirements of the Law of Ukraine "On Waste» and to ensure the further utilization of these wastes. In case of non-compliance by the enterprise with all waste management regulations, a fine is foreseen in accordance with the established legislation. It was shown that the Kiev region belongs to the leaders in the production of livestock products and creates a significant anthropogenic load which is $170 \%$ of the average in Ukraine.

Key words: ecological and economic research, livestock, poultry, products of animal origin.

\section{REFERENCES}

1. Lisitsyin, A.B. (2016). Mirovaya praktika formirovaniya kachestva myasnogo syirya i trebovaniya $\mathrm{k}$ nemu pererabatyivayuschey promyishlennosti [World practice of forming the quality of raw meat and the requirements of the processing industry]. Myasnaya industriya. [Meat industry]. 9, 6-9 (In Russ.)

2. FAO Statistical Pocketbook (2015). Food and Agriculture Organization of the United Nations, 232. Retrived from http://www.fao.org/3/a-i4691e.pdf (In Eng.)

3. Rodić, V. (2006). The influence of instruments for environmental protection to livestock production. Contemporary agriculture. 55 (1-2), 42-47 (In Eng.)

4. Wossink, A. \& Wefering F. (2003). Hot Spots in Animal Agriculture. Emerging Federal Environmental Policies and the Potential for Efficiency and Innovation Offsets. International Journal Agricultural Resources, Governance and Ecology. 2, 228-242 (In Eng.)

5. German, V.V. (2009). Ekologichna bezpeka pry vyrobnytstvi tvarinnitskoyi produktsiyi [Ecological safety in the production of livestock products]. Ahroekologichniy zhurnal. [Agroecological journal]. 2, 5-8 (In Ukr.)

6. Masberg, I.V., Keyvan, M.P., Tertychna, O.V. and Brigas, O.P. (2014). Bioindikatsiya stanu atmosfernogo povitrya $\mathrm{v}$ zoni diyalnosti tvarinnitskih kompleksiv [Bioindication of the state of atmospheric air in the area of livestock complexes]. Ahroekologichniy zhurnal [Agroecological journal]. 1, 40-42 (In Ukr.)

7. Moklyachuk, L.I., Lukin, S.M., Kozlova, N.P. and Martkoplishvili, M.M. (2014). Zagryaznenie okruzhayuschey sredyi himicheski aktivnyim azotom iz selskohozyaystvennyih istochnikov: problema i puti resheniya [Environmental contamination with chemically active nitrogen from agricultural sources: a problem and solutions]. Ahroekologichniy zhurnal [Agroecological journal]. 1, 13-21 (In Russ.)

8. Tertychna, O.V. \& Boroday, V.P. (2015). Ekologichni zasadi rozvytku promislovogo ptahivnitstva [Ecological principles of development of industrial poultry farming]. Ahroekologichniy zhurnal [Agroecological journal]. 2, 6-12 (In Ukr.)

9. Boyko, L.O., Boyko, V.O. and Avercheva, N.O. (2016). Rozrobka prognozu ta perspektivi rozvitku galuzi ptahivnitstva do 2020 roku [Development of forecast and prospects for poultry industry development till 2020]. Tehnologicheskij audit $i$ rezervy proizvodstva [Technological audit and production reserves]. $4 / 6$ (30), 34-40 (In Ukr.)

10. The official site of the State Statistics Service of Ukraine. [Electronic source]. URL: http://www.ukrstat. gov.ua (In Ukr.)

11. The Verkhovna Rada of Ukraine (2015), The Law of Ukraine «On by-products of animal origin not intended for human consumption». Retrieved from: http://zakon.rada.gov.ua/ (date of accesse: 21.03.2019).

12. Tertychna, O.V., Pinchuk, O.V., Boroday, V.P. and Stepanov, R.A. (2016). Tendentsiyi rozvitku ta ekologichni problemi promislovogo tvarynnytstva suchasnoyi aglomeratsiyi [Development trends and environmental problems of industrial livestock in modern agglomeration]. Visnyk ahrarnoi nauky [Bulletin of Agrarian Science]. 6, 54-59 (In Ukr.)

\section{Authors}

Furdychko Orest Ivanovych - Doctor of Economics, Doctor of Agricultural Sciences, Professor, Academician of the National Academy of Sciences of Ukraine, Director, Institute of Agroecology and Nature Management of NAAS (Ukraine, 03143, Kyiv, 12 Metrologichna St.; e-mail: agroecologynaan@ gmail.com)

Svalyavchuk Larysa Ivanivna - Candidate of Biological Sciences, Research Officer, Institute of Agroecology and Nature Management of NAAS (Ukraine, Kyiv; e-mail: svaliavchuklarisa@ukr.net)

Shevtsova Olha Leonidivna - Head of the Department of Scientific Personnel and Graduate Studies of the National Academy of Agrarian Sciences of Ukraine (Ukraine, Kyiv; e-mail: vnka@naas. gov.ua). 